\title{
Ameliyat Tekniği, Yaş, Cinsiyet ve Lezyonun Bölgesi Nüks Oranını Etkiler mi? Anevrizmal Kemik Kistinin (AKK) Epidemiyolojik Çalışması
}

Does Treatment Technique, Age, Sex and Lesion Side Effect the Rate of

\section{Recurrence? An Epidemiologic Study of Aneurysmal Bone Cysts} Alauddin Kochai', Buğra Alpan², Ünal Erkorkmaz ${ }^{3}$, Harzem Özger²

'Sakarya Üniversitesi Tıp Fakültesi, Ortopedi ve Travmatoloji Anabilim Dalı

${ }^{2}$ Acıbadem Maslak Hastanesi, Ortopedi ve Travmatoloji Kliniği

${ }^{3}$ Sakarya Üniversitesi Tıp Fakültesi, Biyoistatistik Anabilim Dalı

\section{Yazışma Adresi / Correspondence:}

\section{Alauddin Kochai}

Sakarya Universitesi Egitim Arastirma Hastanesi

Adnan Menderen Caddesi Saglik Sok No: 195 Erenler 54100 Sakarya/ Turkey

T: +905323275562 E-mail: alkoc79@gmail.com

Geliş Tarihi / Received : 22.05.2018 Kabul Tarihi / Accepted : 04.09.2018

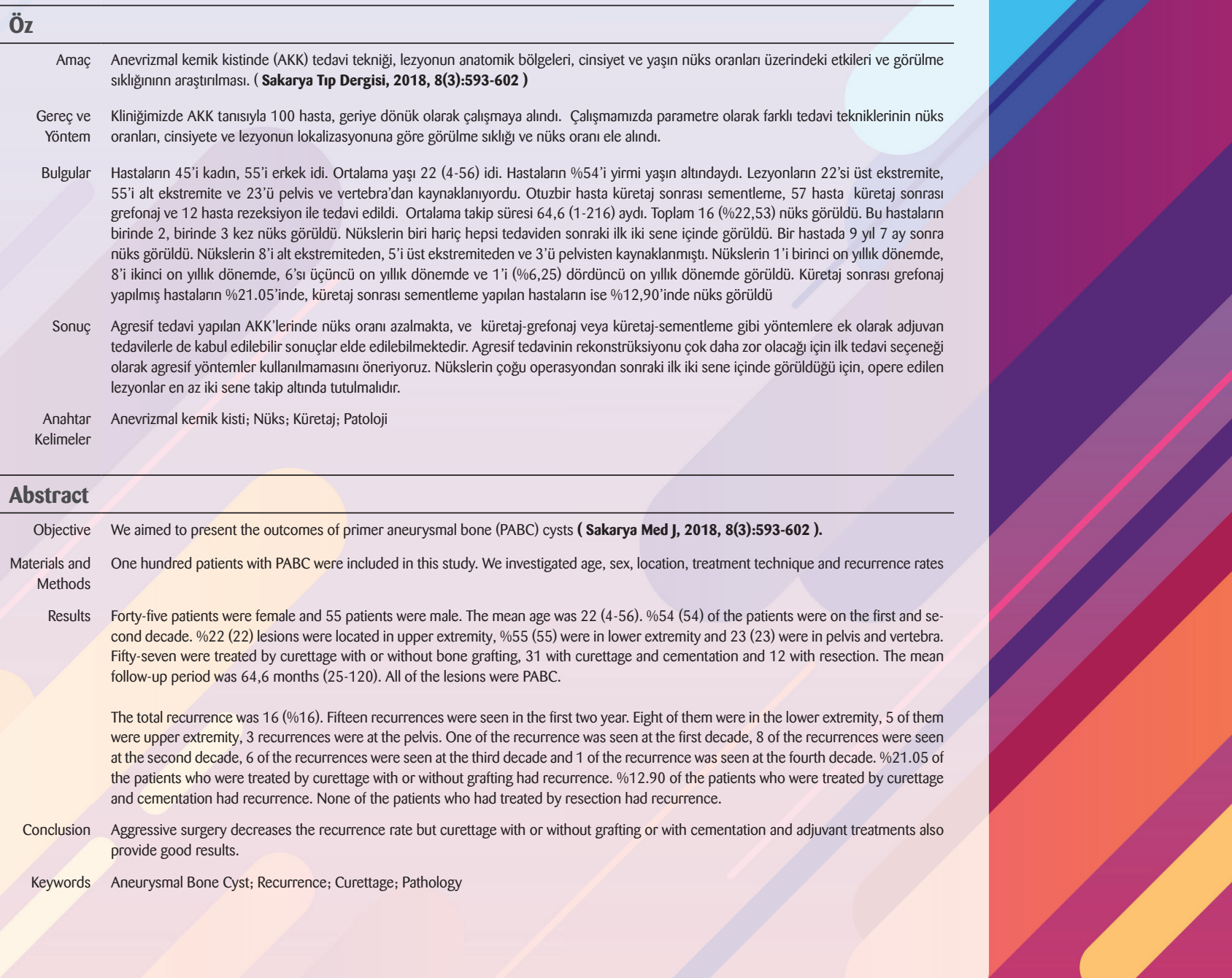


Sakarya TIp Dergisi 2018;8(3):593-602

\section{Giriş}

Anevrizmal kemik kistleri (AKK) en sık ikinci dekatta görülen kemiğin kistik lezyonlardır. AKK tüm kemik tümörlerinin yaklaşık \%1'ini oluşturmaktadır. Osteosarkoma oranla 4-7 kez daha az görülmektedir ${ }^{1}$. Tüm iskelet sisteminde görülmesine karşın, sıklıkla (\%65) uzun kemiklerde görülür ve kadınlarda erkeklere nazaran daha sık rastlanı ${ }^{2,3}$.

Etyolojisi tam olarak aydınlanamamıştır ve bu konuda çok sayıda teori öne sürülmüştür. En çok kabul edilen etyoloji, lezyon bölgesinde vasküler malformasyonun veya hemodinamik değişikliklerin sebep olduğudur ${ }^{4}$.

Anevrizmal kemik kistlerinin \%30'u başka bir patoloji sonucu gelişebilir. Başka bir patolojiye sekonder gelişen bu olguların ancak üçte birinde primer lezyonun tanısı konulabilmektedir. ${ }^{3,5}$ Bunların en sık (\%19-39) görüleni dev hücreli kemik tümörüdür. Bu sebepten dolayı tüm kemik tümörlerinde olduğu gibi AKK'nın de tanı ve tedavisinde kliniko-patolojik yaklaşım son derece önemlidir. Bu nedenle cerrah, patolog, radyolog ve onkologlar (medikal ve radyasyon) vakaları birlikte değerlendirmelidir.

Anevrizmal kemik kistlerinin görülme sıklı̆ı 1.4/100,000‘dir ancak klinikopatolojik özellikleri, yanlış tanı koyulması, sekonder olması, kendiliğinden kaynaması, ilerleme göstermemesi, bazen semptom oluşturmaması özelliklerinden dolayı insidansı tam olarak belirlenememiştir.

Bu çalışmada AKK sıklığı, yaşa, cinsiyet ve lokalizasyona göre dağılım ve nüks oranının belirlenmesi, ayrıca, tedavi sonuçların nüks oranı üzerindeki etkilerinin gösterilmesi amaçlamıştır.

\section{Gereç Ve Yöntemler}

Kliniğimizde 2004-2010 tarihleri arasında AKK tanısıyla opere edilen 120 hasta retrospektif olarak incelendi. Çalışmaya alınmayan hastaların 4 'ünde preoperatif alınan biyopsisinde AKK saptanmamış olması, 12 hastanın çeşitli nedenlerden dolayı takipleri yapılamamış olması ve 4 hastada patolojik kırık sonrası tanı konmuş olması nedeniyle çalışmadan çıkarıldı. Toplam 100 hasta çalışmaya dahil edildi. Bütün hastaların preoperatif histopatolojik tanıları insizyonel veya trucut biyopsisiyle AKK olarak konulmuştu. Lezyonların hepsi primer AKK'ydı. Sekonder AKK' ye rastlanmadı. Hastaların başlangıç şikayetleri ağıı, şişlik ya da patolojik kırıktı.

Çalışmamızda parametre olarak farklı tedavi tekniklerinin nüks oranları, cinsiyete göre nüks oranı, yaşa göre görülme sıklı̆ı ve nüks oranı ve lezyonun lokalizasyonuna göre görülme sıklı̆ı ve lezyonun lokalizasyonuna göre nüks oranı ele alındı.

Çalışmada nüks sayıları yönünden yapılan karşış̧̧ırmalarda ki-kare testleri kullanıldı. Sonuçlar sayı (n) ve yüzde (\%) olarak gösterildi. Yaş ortalamaları yönünden yapılan karşılaşıırmalarda bağımsız iki örneklem t testi kullanıldı. $p$ değerleri $<0.05$ istatistiksel olarak anlamlı kabul edildi. Hesaplamalar hazır istatistik yazılımı ile yapıldı (IBM SPSS Statistics, Version 23.0. Armonk, NY: IBM Corp.)

Bu araştırma kesitsel tipte tanımlayıcı bir çalışmadır. 


\section{Bulgular}

Hastaların ortalama yaşı 22 (4-56) idi. Lezyonların 52'si (\%52) 20 yaşın altında görülmüştü. Ortalama takip süremiz 64,6 (25-120) aydı.

Yüz hastanın 45'ü kadın ve 55'i erkek idi. Çalışmamızda kadın ve erkek arasında nüks açısından anlamlı fark gözlenmemiştir. (Tablo 1).

\begin{tabular}{|c|c|c|c|c|c|}
\hline & & Yaş Ort. & Toplam n (\%) & Nüks n (\%) & $\rho$ \\
\hline \multicolumn{2}{|l|}{ Toplam } & 22 & $100(100)$ & $16(16)$ & \\
\hline \multirow{2}{*}{ Cinsiyet } & Kadın & 23,23 & $45(45)$ & $7(15.55)$ & \multirow{2}{*}{0.927} \\
\hline & Erkek & 21,05 & $55(55)$ & $9(16.36))$ & \\
\hline \multirow{6}{*}{ Yaş Grupları } & $4-10$ & 6 & $8(8)$ & $1(12,5)$ & \multirow{6}{*}{0.375} \\
\hline & $11-20$ & 15,77 & $44(44)$ & $8(18,18)$ & \\
\hline & $21-30$ & 25,18 & $30(30)$ & $6(20)$ & \\
\hline & $31-40$ & 34,37 & $11(11)$ & $1(9,09)$ & \\
\hline & $41-50$ & 43,7 & $5(5)$ & - & \\
\hline & $51-60$ & 56 & $2(2)$ & - & \\
\hline \multirow{4}{*}{ Lokalizasyon } & Üst Ekstremite & & $22(22)$ & $5(22.7)$ & \multirow{4}{*}{0.515} \\
\hline & Alt Ekstremite & & $55(55)$ & $8(14.54)$ & \\
\hline & Pelvis & & $22(22)$ & $3(13.63)$ & \\
\hline & Vertebra & & $1(1)$ & - & \\
\hline \multirow{3}{*}{$\begin{array}{l}\text { Yapilan } \\
\text { operasyon }\end{array}$} & Küretaj sementleme & & $31(31)$ & $4(12.9)$ & \multirow{3}{*}{0.375} \\
\hline & Küretaj grefonaj & & $57(57)$ & $12(21.05)$ & \\
\hline & Rezeksiyon & & $12(12)$ & - & \\
\hline
\end{tabular}

Anevrizmal kemik kistlerinin görülme yaşlarına bakıldığında, ikinci ve üçüncü dekatta daha sık tanı konulduğu görüldü. Sekiz hasta (\%8) birinci dekatta, 44 hasta (\%44) ikinci dekatta, 30 hasta (\%30) üçüncü dekatta, 11 hasta (\%11) dördüncü dekatta, 5 hasta (\%5) beşinci ve 2 hasta (\%2) altıncı dekattaydı. AKK ikinci ve üçüncü dekatta daha sık görüldüğü gibi nüsleri de ikinci ve üçüncü dekatta daha sıktı. Nüklerin 9'u $(\% 56,25) 20$ yaşın altında görüldü. Yaş grupları arasında nüks farklıı̆ı olmadığı görüldü (Tablo 1)

Lokalizasyona göre AKK'nın sıklığı incelendiğinde, lezyonların 22'sinin (\%22) üst ekstremiteden, 55 'inin (\%55) alt extremiteden kaynaklandığı görüldü. Lezyonların 22'si (\%22) pelvis ,1'i (\%1) vertebra yerleşimliydi. Nükslerin 8'i (\%50) alt ekstremiteden, 3’ü $(\% 18,75)$ pelvisten, 5 'i $(\% 31,25)$ üst ekstremiteden kaynaklanmıştı. Üst ekstremite nükslerinin 3'ü humerus, 2'si de radius kaynaklı idi. Lokalizasyonlar arasında nüks görülme açısında herhangi bir fark olmadığı gözlendi (Tablo 1)

Otuz bir hasta (\%31) küretaj sonrası sementleme ile tedavi edildi. Bu hastaların 4'ünde nüks görüldü. Küretaj sonrası sementleme yapılan hastaların \%12,90'ında nüks görüldü. Bu oran bütün nükslerin \%25 ini oluşturmaktaydı. Elli yedi hasta (\%57) küretaj sonrası grefonaj ile tedavi edilmişti. Bu hastaların 12'sinde nüks görüldü. Küretaj sonrası grefonaj yapılmış hastaların \%30'unda nüks görülmüştü. Bu oran bütün nükslerin \%75' ini oluşturmaktaydı. Rezeksiyon ile 12 hasta tedavi edilmişti. Bu vakaların hiçbirinde nüks saptanmadı. Operasyon türleri nüks açısından karşılaştıııldığında istatistiksel olarak anlamlı fark olmadığı görüldü (Tablo 1).
Sakarya Tip Dergisi

2018;8(3):593-602

KOCHAI ve Ark. Anevrizmal Kemik Kistinin Nüks Oranı 


\section{Tartışma}

Anevrizmal Kemik kisti, uzun kemiklerde daha sık olmak üzere tüm iskelette görülebilir. Olguların çoğunluğu ilk iki dekatta görülür. Tanısı için X-ray, Bilgisayarlı tomografi, MRI ve arteriografi gibi görüntüleme yöntemleri kullanılabilir. MRI'de kist içinde septalar bal peteği (honeycomp) görünümümde gözlenir. Bu görütü anevrizmal kemik kistini diğer kistlerden ayırmada yardımcı olmaktadir. ${ }^{4}$

Anevrizmal kemik kistiin etiyolojisi ile ilgili çok sayıda teori öne sürülmüş olsa da tam olarak aydınlatılamamışır. Ama en çok kabul edilen etiyoloji, lezyon bölgesinde vasküler malformasyonun olduğu veya hemodinamik değişikliklerin sebebi olduğu durumlardır. ${ }^{4}$

Anevrizmal kemik kistlerinin \%30'u başka bir patoloji sonucu gelişebilir. Başka bir patolojiye sekonder gelişen bu olguların ancak üçte birinde primer lezyonun tanısı konulabiliyor. ${ }^{3.5}$ Bu çalışmamızda, AKK'nın başka bir patoloji ile birlikteliği gözlenmemiştir.

Anevrizmal kemik kistlerinin görülme sıklğı 1,4/100,000 olup, tüm kemik tümörlerinin \%1'ini oluşturmaktadır. ${ }^{6-7}$ ikinci on yıllık dönemde pik yaparlar. Klinikopatolojik özelliğinden dolayı gerçek sıklığı belirlenememiş̧tir. Yanlış tanı koyulması, sekonder olması, kendiliğinden kaynaması, ilerleme göstermemesi, bazen semptom oluşturmaması özelliklerinden dolayı tam sıklığı hesaplanamamıştır. ${ }^{6}$ Çalışmamızda cinsiyetler arası anlamlı fark gözlenmemektedir (Tablo 1-2).

\begin{tabular}{|c|c|c|c|}
\hline Çalışma & Hasta sayısı & Ortalama yaş & Kadın/Erkek \\
\hline Ramirez $^{7}$ & 37 & 9,8 & $23 / 14$ \\
\hline Arlet $^{8}$ & 28 & 9,1 & $15 / 13$ \\
\hline Bollini9 ${ }^{9}$ & 27 & 10 & $14 / 13$ \\
\hline Dormans $^{10}$ & 26 & 11,2 & $17 / 9$ \\
\hline Carlson $^{11}$ & 25 & 10,5 & $17 / 8$ \\
\hline Moreau $^{12}$ & 17 & 12,4 & $7 / 10$ \\
\hline Epeldegui ${ }^{13}$ & 14 & 11,2 & $8 / 6$ \\
\hline Clough $^{14}$ & 10 & 10,9 & $3 / 7$ \\
\hline Slowick ${ }^{15}$ & 8 & 9,4 & $6 / 2$ \\
\hline Daudet $^{16}$ & 8 & 9 & $5 / 3$ \\
\hline Van Loon ${ }^{17}$ & 7 & 12 & $2 / 5$ \\
\hline Lapeyrie $^{18}$ & 6 & 8,5 & $2 / 4$ \\
\hline Dabska $^{19}$ & 5 & 16 & $3 / 2$ \\
\hline Donaldson $^{20}$ & 5 & 8 & $4 / 1$ \\
\hline Barnes $^{21}$ & 4 & 13 & $2 / 2$ \\
\hline Taylor $^{22}$ & 3 & 11 & $3 / 0$ \\
\hline Cottalorda ${ }^{23}$ & 156 & 9,4 & $56 / 100$ \\
\hline Çalışmamız & 100 & 22 & $45 / 55$ \\
\hline
\end{tabular}

Ancak literatürlere göre çalışmamızda yaş ortalamasının yüksek olduğu görülmüştür. Bunun sebebi olarak tümörün yavaş ilerlemesi, kemik tümörü ile ilgili deneyimli olmayan hekimler tarafından basit kemik kisti gibi düşünülerek takip edilmesi ve bu nedenle de geç tanı konmuş olması düşünülebilir. 
Çoğu çalışmada AKK'nın kadınlarda daha sık görüldüğü gözlenmiştir. ${ }^{5}$ Ancak erkeklerde daha sık görüldüğü ile ilgili çalışmalar da mevcuttur. 8,25 (Tablo 2). Bizim çalışmamızda yapılan cinsiyetler arasındaki karşış̧̧ırmada nüks açısından kadın erkek arasında fark görülmemekle birlikte, erkeklerde anevrizmal kemik kisti insidansi daha yüksek bulunmuştur.

Çoğu yazar çocuklarda tedavi sonrası nüks oranının daha yüksek olduğunu rapor etmiştir. . $^{7,23,25,26}$ İki yüz otuz sekiz hastayı kapsayan bir çalışmada, nüks eden hastaların \%90'। 20 yaşın altında görülmüştür ${ }^{4}$. Atmış altı hastalık bir başka çalışmada nüks eden hastaların çoğunun 15 yaş altında olduğu bildirilmiştir ${ }^{27}$. Yirmi dokuz hastalık bir başka çalışmada nükslerin \%75'i 5 yaş ve altı çocuklarda görülmüştür. Bir başka çalışmada 10 yaşın altındaki çocukların \%71'inde nüks görülmüştür ve bunun sebebi olarak da çocuklarda AKK'nın daha agresif seyrettiği düşünülmüştür?. Bir başka sebep de ameliyat sırasında fiz plaklarını korurken rezidüel tümör dokusunun kalmasıdır. Bir çalışmada 5 yaş altı ve 5 yaş üstü hastalar arasında nüks görülme sıklığının farklı olmadığı̆ görülmüştür. Bu çalışmada, $\leq 5$ yaş olan 21 hastanın 5 'inde nüks görülmüş. Hastaların birinde 6 kez birinde 3 kez ve 3 hastada bir kez nüks görülmüş. Bu çalışmada nüks oranı $5 / 21$ olarak hesaplanmıştır. ${ }^{28}$ Bizim çalışmamızda $\leq 5$ yaş 2 hasta olup, hastalarda nüks görülmemiştir. Ek olarak $4-10$ yaş arası 8 hasta olup bu hastaların . sadece birinde nüks görülmüştür. Çalışmamızda 5 yaş altı ve 5 yaş üstü hastalar arasında nüks oranında anlamlı farklılık gözlenmemiştir. Yaşlar arasında istatistiksel olarak nüks farklılığı olmadığı görülmemiştir. (Tablo 1- 2)

Yapılan çalışmalarda nükslerin çoğunun tedaviden sonraki ilk iki yıl içinde olduğu görülmüştür. Yirmi bir hastalık bir çalışmada nüksler ortalama olarak 7,6 ayda (3-13 ay) görülmüştür. ${ }^{23}$ Altmış altı hastalık bir başka çalışmada, nüks görülen 26 hastanın 24'ü ilk yıl içinde nüksetmiştir. Doksan beş hastalık bir çalışmada nüks edenlerin hepsi (biri hariç) tedaviden sonraki ilk iki sene içinde görülmüştür. ${ }^{29}$ Son çalışmaya benzer olarak bizim çalışmamızda da nükslerin hepsi (biri hariç) ilk iki senenin içinde görülmüştür. Nükslerin ortalama olarak 13,6 ayda (2-25 ay) olduğu gözlemlenmiştir.. Bir hastamızda 9 yıl 7 ay sonra nüks tespit edilmiştir. Literatürle de benzerlik gösterdiği gibi bizim çalışmamızda da AKK'lerin çoğu ameliyattan sonraki ilk iki sene içinde nüks etmektedir. Literatürlerde olduğu gibi çalışmamızda da AKK femur, tibia, humerus, fibula, radius ve pelviste sık görülür. ${ }^{23}$ (Tablo 1). Literatürden farklı olarak çalışmamızda vertebra tutulumu daha az görülmektedir (Tablo 1-3). Çalışmamızda lokalizasyonlar arasında yapılan istatiksel karşılaştırmalara göre nüks görülme açısından herhangi bir fark görülmediği gözlenmiştir.
Sakarya Tip Dergis

2018;8(3):593-602

KOCHAI ve Ark Anevrizmal Kemik Kistinin Nüks Oranı 
Tablo 3. Lezyonun tutulum yerlerine göre literatür incelemeleri ve çalışmamızda lezyonun tutulum yerleri tabloda belirtilmiş.

\begin{tabular}{|l|c|c|c|}
\hline Lezyonun yeri & ${\text { Literatür çalısması }{ }^{23}}^{3}$ & Çalısmamız & Toplam \\
\hline Femur & 91 & 28 & 119 \\
\hline Tibia & 71 & 20 & 91 \\
\hline Vertebra & 60 & 1 & 51 \\
\hline Humerus & 43 & 13 & 49 \\
\hline Pelvis & 36 & 19 & 40 \\
\hline Fibula & 34 & 6 & 12 \\
\hline Klavikula & 12 & 0 & 16 \\
\hline Radius & 11 & 5 & 9 \\
\hline Kaburgalar & 9 & 0 & 8 \\
\hline Metakarp & 8 & 0 & 6 \\
\hline Ulna & 6 & 0 & 6 \\
\hline Skapula & 6 & 0 & 6 \\
\hline Kalkaneus & 6 & 0 & 6 \\
\hline Phalanks & 4 & 2 & 6 \\
\hline Talus & 3 & 3 & 3 \\
\hline Metatars & 3 & 0 & 5 \\
\hline Sakrum & 2 & 3 & 508 \\
\hline Karpal & 408 & 0 & 2 \\
\hline Kuneiform & & & \\
\hline Toplam & 3 & 00 & \\
\hline
\end{tabular}

Tablo 4 ‘te küretaj sonrası grefonaj veya sadece küretaj yapılan ile ilgili literatür incelemesi görülmektedir. Bu incelemede 747 hastaya küretaj ve grefonaj veya grefonajsız küretaj yapılmış. Hastaların 227 'sinde $(\% 30,38)$ nüks görülmüştür. Bizim çalışmamız da literatüre ile paralellik göstermektedir.

Anevrizmal kemik kistinin klasikleşmiş tedavisi olan küretaj, en sık kullanılan yöntemdir. Yapılan 690 hastalık bir çalışmada grefonaj ile birlikte veya grefonajsız küretaj yapılan hastaların \%31,1'inde nüks görülmüştür (Tablo 4). Bizim çalışmamızda grefonajsız veya grefonaj ile küretaj yapılan hastaların \%21.05’unda nüks görülmüştür (Tablo 1). Çalışmamız literatür ile uygunluk göstermektedir. Bu nüks oranının \%50'ye varabildiğini rapor edilmiştir. ${ }^{27}$ Küretaj için açılan pencerenin genişliği kistin içini temizleme açısından büyük önem taşımaktadır. Cole çalışmasında küçük bir delikten küretaj yapmış ve küretaj sonrası baktığında, çok sayıda tümör dokusunun kavite içerisinde kaldığını görmüştür ve küçük bir delikten küretaj yapmanın yetersiz küretaj olduğunu vurgulamıştı. ${ }^{30}$ Dormons ve ark yaptıkları çalışmada geniş açılan pencerenin (lezyonun \%70-90) kistin içini temizlemeyi ve görmeyi kolaylaştırdığını bildirmişlerdir. ${ }^{10}$ Anevrizmal kemik kistinin içini iyice temizleyebilmek için yeteri kadar pencere açılması gerekmektedir. Böylelikle rezidüel tümör dokusu azaltılarak nüks oranı düşürülebilecektir. 


\begin{tabular}{|c|c|c|c|}
\hline Çalışma & Hasta Sayısı & Nüks sayısı & Yüzde \\
\hline Campanacci $^{3}$ & 91 & 19 & $\% 20.8$ \\
\hline Vergel de Dios $^{24}$ & 124 & 27 & $\% 21.7$ \\
\hline Mankin ${ }^{31}$ & 110 & 24 & \% 21.8 \\
\hline Marcove ${ }^{32}$ & 44 & 26 & $\% 59$ \\
\hline Ruiter $^{25}$ & 82 & 28 & $\% 31.1$ \\
\hline Ozaki ${ }^{33}$ & 30 & 11 & $\% 36.6$ \\
\hline Biesecker $^{27}$ & 44 & 26 & $\% 59$ \\
\hline Nobler ${ }^{103}$ & 18 & 6 & \% 33.3 \\
\hline Clough ve Price ${ }^{35}$ & 15 & 6 & $\% 40$ \\
\hline Koskinen $^{36}$ & 14 & 2 & $\% 14.2$ \\
\hline Server Perez ${ }^{26}$ & 17 & 4 & \% 23.5 \\
\hline Farsetti $^{37}$ & 11 & 2 & $\% 18.1$ \\
\hline Ramirez $^{7}$ & 24 & 8 & \% 33.3 \\
\hline Arlet $^{8}$ & 11 & 4 & $\% 36.3$ \\
\hline Bollini $^{9}$ & 12 & 5 & $\% 41.6$ \\
\hline Cole $^{30}$ & 18 & 7 & \% 38.8 \\
\hline Epeldegui Torre ${ }^{13}$ & 13 & 4 & $\% 30.7$ \\
\hline Ozaki et al ${ }^{38}$ & 5 & 1 & $\% 20$ \\
\hline Freiberg ${ }^{39}$ & 7 & 5 & $\% 71.4$ \\
\hline Çalışmamız & 57 & 12 & $\% 21.05$ \\
\hline Toplam & 747 & 227 & $\% 30,38$ \\
\hline
\end{tabular}

Sakarya Tıp Dergisi

2018;8(3):593-602

KOCHAI ve Ark

Anevrizmal Kemik Kistinin Nüks Oranı

Küretaj sonrası nüksü azaltmak için küretaj sonrası rezidü dokuyu azaltmak gerekir. Rezidüel dokuyu azaltmak için çeşitli çalışmalar yapılmış ve bu amaçla yüksek hızlı motor ile kistin içinin drillenmesi önerilmiştir. Gibbs ve ark yaptıkları çalışma sonucunda, drilleme ile rezideül dokunun en düşük seviyeye indirilebileceği gösterilerek nüks oranını \%12'ye kadar düşürmüştür ve küretaj ve yüksek hızlı motor ile kistin içinin drillemesinin tek tedavi olarak düşünülmesi gerektiği belirtilmiştir. ${ }^{40}$

Küretaj sonrası adjuvan tedaviler de nüksleri azaltmak için kullanılabilir. Fenol non-selektif sitotoksik bir ajandır. Sitotoksik özelliği sayesinde adjuvan tedavi olarak kullanılmaktadır. ${ }^{41}$ Sıvı nitrojen ile kryoterapi de kistin içinde küretaj sonrası kalan tümör hücrelerini öldürmek için adjuvan tedavi olarak kullanılabilir. kullanılır. Fenol yüzeyel etki gösterdiği için kemiğin derin bölgelerinde olan tümör hücrelerine etki etmemektedir ${ }^{41}$. Bu sebeple cryoterapiye oranla nüks oranı daha yüksektir. Marcove ve ark yaptıkları bir çalısmada, küretaj sonrası kaviteye sıvı nitrojen vererek cryoterapi yapmışlar ve bu yöntemle nüks oranını $\% 4$ 'e düşürebilmişlerdir. ${ }^{32}$ Schreuder ve ark ${ }^{42}$ yaptıkları bir çalışmada 27 hastaya küretaj sonrası cryoterapi yapmışlar, hastaların sadece 1'inde nüks görmüşlerdir. Bu çalışmalara bakıldığında küretaj sonrası cryoterapi ile çok iyi sonuçlar elde edilmiş, ancak bu yöntemin çok sayıda komplikasyonları olduğu da bildirilmiştir (Tablo 5). Küretaj sonrası cryoterapi yapılan hastalarda kırık, osteomiyelit, çevre yumuşak dokuların nekrozu, eklem sertliği, osteonekroz, cilt nekrozu, gaz embolizasyonu ve nörovasküler yapılara zarar vermesi gibi çok sayıda komplikasyon rapor edilmiştir. Kullanımı deneyim ve dikkat gerektirir. Ayrıca sıvı nitrogenin kullanılması ve mühafaza edilmesi zordur. Literatür incelemelerinde cryoterapi yapılan 85 hastanın 11 'inde nüks görülmüştür (Tablo 5). 


\begin{tabular}{|l|c|c|c|}
\hline \multicolumn{5}{|l|}{ Tablo 5. Literatür incelemelerinde cryoterapi yapılan hastalarda nüks sayısı. } \\
\hline Çalışma & Hasta Sayısı & Nüks Sayısı & Yüzde \\
\hline Marcove $^{32}$ & 51 & 9 & $\% 17,6$ \\
\hline Bieceker $^{27}$ & 7 & 1 & $\% 14,2$ \\
\hline Schreuder $^{42}$ & 27 & 1 & $\% 3,7$ \\
\hline Toplam $^{27}$ & 85 & 11 & $\% 12,9$ \\
\hline
\end{tabular}

Kemik çimentosu ile adjuvan tedavi, çimentonun ısı oluşturma özelliğine bağlıdır. ${ }^{33}$ Bir hücre üzerinde öldürücü termal etki oluşturabilmek için sıcaklığın en az 50 0C'ye kadar çıkması gerekir. ${ }^{33}$ Termal etki kortikal bölgede $0.5 \mathrm{~mm}$, spongioz bölgede $2.5 \mathrm{~mm}$ kemiğin üzerinde etki gösterebilir $^{33}$. Ozaki T ve ark'nın ${ }^{33}$ yaptığı bir çalışmada, 30 hastaya küretaj sonrası grefonaj yapılmış, 35 hastaya da küretaj sonrası kaviteyi doldurmak için çimento kullanılmıştır. Küretaj sonrası grefonaj yapılan hastaların \%37’sinde nüks görülürken, küretaj sonrası sementleme yapılan hastaların \%17’sinde nüks görülmüştür. Bizim çalışmamızda 31 hastaya küretaj sonrası sementleme yapılmış, 57 hastaya da küretaj sonrası grefonaj yapılmıştır. Küretaj sonrası sementleme yapılan hastaların 4’ünde (\%12,9), küretaj sonrası greftleme yapılan hastaların 12'sinde (\%21.05) nüks görülmüştür (Tablo 1-6).

\begin{tabular}{|l|c|c|}
\hline \multicolumn{3}{|l|}{ Tablo 6. Küretaj ve sementleme yapılan hastaların literatür incelemesi } \\
\hline Çalışma & Hasta Sayısı & Nüks Sayısı \\
\hline Mankin $^{31}$ & 20 & 5 \\
\hline Ozaki et al $^{33}$ & 35 & 6 \\
\hline Ozaki $^{38}$ & 5 & 1 \\
\hline Çalışmamız $^{3}$ & 31 & 4 \\
\hline Toplam & 91 & 12 \\
\hline
\end{tabular}

Sementin adjuvan etkisinin yanında, greftleye göre erken gelişen nüksleri tespit etmede radyolojik olarak daha üstün olduğu görülmektedir. Nüks cerrahisi sırasında çıkarılan sementten biyopsi alınabilir. ${ }^{33}$ Çimentonun uygulanmasının kolay olması ve özellikle küretaj yapılan bölgeye yapısal destek oluşturması avantajları arasındadır. ${ }^{33}$ Ancak çalışmamızda küretaj+sementleme ve küretaj+grefonaj yapılan hastalar nüks açısından karşılaştırıldığında istatistiksel olarak anlamlı fark olmadığı görülmüştür.

Embolizasyon kistin kanlanmasını azaltarak ameliyat sırasında kanamayı azaltmaktadır. Küretaj öncesi ve özellikle turnike kullanılamadığı yerlerde etkili olmakta ve böylelikle daha etkili bir küretaj sağlanabilmektedir. ${ }^{43-45}$ Selektif arteriyel embolizasyon cerrahi olarak zor olan veya cerrahi komplikasyonlarının fazla olduğu yerlerde etkili bir tedavi yöntemi olarak düşünülmektedir. ${ }^{46}$ Etkili bir selektif arteriyel embolizasyon yapıldığında 2-4 ay içinde ossifikasyon görülebilmektedir. İnvaziv cerrahi bir işlem olmaması sebebiyle anevrizmal kemik kisti için ilk tedavi seçeneği olarak düşünülebilir. Omurgadaki AKK için uygulandığında nöral yapıların iskemisine neden olarak nörolojik defisite neden olabilir. Ancak deneyimli cerrahlar tarafında dikkatli bir şekilde yapıldığında bu risk azalır. ${ }^{43}$ Boriani ve ark torasik bölgede yapılan embolizasyonun torasik kord iskemisine neden olabileceğini bildirmişler ve o bölgedeki Adamkiewicz arterinin tıkanabileceğini öne sürmüşlerdir. ${ }^{47}$ Çalışmamızda sadece 5 hastaya kanamayı azaltmak amacıyla preop embolizasyon yapılmıştır. Hhiçbir hastaya primer tedavi olarak selektif arterial embolizasyon uygulanmamıştır. 
Rezeksiyon, nüksü en az olan yöntemdir. Campanacci ve ark'nın ${ }^{3}$ yaptığı çalışmada rezeksiyon sonrası hiç nüks görülmemiştir. Benzer olarak De Dios'un.24 çalışmasında da rezeksiyon sonrası nüks bildirmemiştir. Yüz yetmiş dokuz hastalık literatür çalışmasında rezeksiyon yapılan hastaların sadece 7’sinde nüks görülmüştür. (Tablo 7).

\begin{tabular}{|c|c|c|}
\hline Çalışma & Hasta Sayısı & Nüks Sayısı \\
\hline Campanacci ${ }^{3}$ & 47 & 0 \\
\hline Vergel de Dios $^{24}$ & 16 & 0 \\
\hline Mankin ${ }^{31}$ & 20 & 1 \\
\hline Ruiter $^{25}$ & 21 & 4 \\
\hline Biesecker $^{27}$ & 8 & 0 \\
\hline Gibbs $^{40}$ & 6 & 0 \\
\hline Nobler $^{34}$ & 8 & 2 \\
\hline Clough ve Price ${ }^{30}$ & 3 & 0 \\
\hline Koskinen $^{36}$ & 5 & 0 \\
\hline Server Perez ${ }^{26}$ & 2 & 0 \\
\hline Farsetti $^{37}$ & 6 & 0 \\
\hline Dormans $^{10}$ & 1 & 0 \\
\hline Ramirez $^{7}$ & 5 & 0 \\
\hline Arlet $^{8}$ & 14 & 0 \\
\hline Bollini $^{9}$ & 11 & 0 \\
\hline Cole $^{30}$ & 2 & 0 \\
\hline Ozaki et a ${ }^{38}$ & 4 & 0 \\
\hline Çalışmamız & 12 & 0 \\
\hline Toplam & 191 & 7 \\
\hline
\end{tabular}

Nüks olan hastalara marginal rezeksiyon yapılmıştır. Geniş rezeksiyon yapılan hastaların hiçbirinde nüks görülmemiştir. ${ }^{48}$ Literatüre bakıldığında rezeksiyon sonrası nüks oranının çok düşük olduğu görülmektedir. Çalışmamız ise literatür çalışmaları ile paralellik göstermektedir. Rezeksiyon yöntemi, morbiditesi fazla olduğu için ve çıkarlan kemiği rekonstrükte etmek için ek bir cerrahi işlem gerektiğinden çok fazla tercih edilen bir yöntem değildir. Daha az agresif yöntemlerle kabul edilebilir sonuçlar elde edilebildiği için bu yöntemin fonksiyonel sorun yaratmayacağı yerlerde kullanılması önerilir ${ }^{35}$.

\section{Sonuç}

Agresif tedavi yapılan AKK hastalarında nüks oranı azaldığı görülmekte birlikte küretaj+grefonaj veya küretaj+sementleme gibi yöntemlere ek olarak adjuvan tedavilerle de kabul edilebilir sonuçlar elde edilebilmektedir. Agresif tedavinin rekonstrüksiyonu çok daha zor olacağı için ilk tedavi seçeneği olarak agresif yöntemlerin kullanılmamasını öneriyoruz. Nükslerin çoğu operasyondan sonraki ilk iki sene içinde görüldüğü için, opere edilen hastaların en az iki sene takip altında olması akılda tutulmalıdır.
Sakarya Tıp Dergisi 2018;8(3):593-602

KOCHAI ve Ark. Anevrizmal Kemik Kistinin Nüks Oranı 
1. Szendröi M, Konya A, Renyi-Vamos A. Aneurysmal Bone cysts. A review of 52 primer and 16 seconder aneurysmal bone cysts. Arch Orthop Trauma Surg. 111-318 -322, 1992

2. Campanacci M. Aneurysmal bone cyst. In: Campanacci M ( editor): bone and soft tissue tumors. 2nd ed. New-York: springer- verlag; 1999, pp 813-840

3. Campanacci M, Capanna R, Picci. Unicameral and aneurysmal bone cysts. Clin Orthop 1986; 204:25-36

4. Lichtentein, Louis. Aneurysmal Bone cysts. Further Observation. Cancer, \&:1228-1237, 1953

5. Kransdorf MJ, Sweet DE. Aneuryzmal bone cyst: consetp, controversy, clinical presentation, and imaging. AJR 1995; 164:573-80.

6. Leithner A, Windhager R, Lang S, Hass OA, Kainberger F, kotz R, Anevrizmal bone cyst. A papulation based epidemiologic study and literature review . Clin orthop 1999;363:176-179

7. Ramirez AR, Stanton RP. Aneuryzmal bone cyst in 29 childern.J Pediatr Orthop B 2002 22:533-539

8. Arlet V, Rigault P. Paovani JP, et al. Le Kyste anuvryzmal de sos chez l'enfant. Etude de 28 cas ( aneurysmal bone cysts in children. A study of 28 cases). Rev Chir Orthop; 73:337-348.

9. Bollini G, Jouve JL, Cottalorda J et al. Aneurysmal bone cysts in children analysis of twenty-seven patients. J Pediatr Orthop B 1998;7:274-285

10. Dormans JP, Hanna BG, Johnston DR, et al. Surgical Treatment and Recurrens Rate of Aneurysmal Bone Cysts in children. Clin Orthop 2004 421:205-211

11. Carlson DH, Wilkinson RH Bhakkaviziam A. Aneurysmal bone cysts in Children. Am J Roentgenol 1972;116:644-650.

12. Moreau CA. Aneurysmal bone cyst [in Franch]. Ann Orthop Quest 1981 13:47-53

13. Epeldegui Torre T. Aneurysmal bone cyst. In: Bone tumors in children and adolescents. Mapfre Medicina 1997;8(suppl I):160-165

14. Clough JR, Price HG. Aneurysmal bone cyst: pathogenesis and long term results of treatment. Clin Orthop 1973; 97:52-63

15. Slowick FA Campbell C) Kettelkamp DB. Aneurysmal bone cyst: an analis of thirteen cases. J Bone Joint Surg Am 1968; 50A:1142-1151

16. Daudet M. Marion J, Faysse R, Vauzelle JL, Baulieu J, Rebouillat J, Lapras C. Aneurysmal bone cyst in children [in Franch]. Ann Chir Infant 1971; 12:7-34

17. Van Loon CJM, Veth RPH, Pruszczynski M, Lemmens JAM, Van Hom JR. Aenurysmal bone Cysts. Long-term results and functional evaluation. Acta Orthop Belg 1995;6:199-20

18. Lapyrie M, Picard JJ, Pous JG. Aneruysmal bone cyst: about 7 cases [in Franch]. Rev Chir Orthop $1965 ; 51: 545-556$

19. Dabska M, BuraczewskiJ. Aneurysmal bone cyst. Pathology, clinical course and radiologic Appearances. Cancer 1969;23:371-389.

20. William F. Donaldson JR. Aneurysmal Bone Cysts. J Bone Joint Surg Am. 1962:44:25-40

21. Barnes R. Aneurysmal bone cyst. J Bone Joint Surg Br 1956; 38B: 301 . 311

22. Taylor FW. Aneurysmal bone cyst. Report of three cases. J Bone Joint Surg Br 1956. 38B.293-300

23. Cottalorda J. Epidemiology of aneurysmal bone cyst in childern a multicenter study and literature review. J Pediatr Orthop B. 2004 Nov:13(6):389-94. Review

24. Dios V. D. AM, Bond JR, Shives TC, Mc leod RA, Unni KK. Aneuryzma bone cyst. A clinicopathologic study of 238 cases . Canser 1992 $69.2921-2931$.
25. Ruiter DJ, Van Rijssel TG, Vander Velde EA. Aneurysmal bone cysts: A clinicopatholgy of 105 cases. Cancer 1977, 39.2231-2239

26. Server Perez F, Gomez bensfills X, Mateo Montanes X, Garcia Garcia C Casamitjana J, Vidal Homs E. Aneurysmal bone cysts: review of 20 case [infrench]. Acta Ortop Belg 1980; 46:272-288

27. Biesecker JL, Marcove RC. Huvos AG. Mike V. Aneurysmal bone cysts. A clinicopathologic study of 66 cases. Cancer 26(3):615-625

28. Cottalorda J, Kohler R Chotel F, et al. Recurrence of aneurysmal bone cysts in young children : a multicenter study. J Pediatr Orthop B 2005 ; 14: 212-218

29. Tilmann's BP, Dahlin DC, Lipscomb PR, Steewaart JR. Aneurysmal bone cysts, analisis of 95 cases. Mayo Clin Proc 1968; 43:478-495

30. Cole WG. Treatment of aneurysmal bone cysts in childhood. J Pediatr Orthop 1986; 6:326-329

31. Mankin HJ, Hornicek FJ, Ortiz-Cruz E, et al. Aneurysmal Bone Cysts: A review of 150 patients. J Clin Oncol 2005;23:6756-6762

32. Marcove RC, Sheth DS, Tekemoto S, et al. The treatment of aneurysma bone cyst. Clin Orthop 1995;311:157-163

33. Ozaki T, Hillmann A, Lindner $\mathrm{N}$, et al. Cementation of primer aneurysmal bone cysts. Clin Orthop 1997:337:240-248

34. Nobler MP, Higinbotham NL, Philips RF. The cue os anuerysmal bone cyst: Irradation superior to surgery in an analysis of 33 cases. Radiology 1968:90:1185-1192

35. Clough JR, Price HG. Aneurysmal bone cyst: pathogenesis and long term results of treatment. Clin Orthop 1973; 97:52-63

36. Koskinen EVS, Visuri TI, Holmström T, et al. Aneurysmal bone cyst. Evaluation of resection and curettage in 20 cases. Clin Orthop 1976 118:136-146

37. Farsetti P, Tudisco C,Rosa M, et al. Aneurysmal bone . Long term follow up of 20 cases. Arch Orthop Trauma Surg 1990;109:221-223

38. Ozaki, Hillmann A, Lindner $\mathrm{N}$, et al. Aneurysmal bone cysts in children. Cancer Res Clin Oncol 1996; 122:767-769.

39. Freiberg AA, Loder RT, Heidelberger KP, et al . Aneurysmal bone cysts in young children. J pediatr Orthop 1994; 14:86-91

40. Gibbs CP, Helefe MC peabody TD, et al. Aneurysmal bone cysts of the extremities: factors related to local recurrence after curettage with a highspeed burr. J Bone Joint Surg [Am] 1999;81:1671-1678

41. Capanna R, Sudanese A, Baldini N, Campanacci M. Phenol as an adjuvant in the control of local recurrence of benign neoplasms of bone treated by curettage. Ital J Orthop Traumatol $1985 ; 11: 381-8$

42. Schreuder HWB, Veth RPH, Pruszczynski M, et al. Aneurysmal bone cysts treated by curretage, Cryotherapy and grafting. J Bone Joint Surg [Br] 1997;79:20-25

43. Green JA, Bellemore MC Marsden FW. Embolization in treatment of aneurysmal bone cysts. J Pediatr Orthop 1997 ; 17:440-443

44. Cristofaro R, Biagini R, Boriani S, et al. Selective artrial embolization in the treatment of aneurysmal bone cysts and angioma. Skeletal Radiol 1992, 2:523-527

45. Dick HM, Bigliani LU, Michelsen WJ, et al. Adjuvant arterial embolization in the treatment of benign primer bone tumors in children. Clin Orthop 1979 139:133-141

46. Cisneros AJ, Gomez CH Benedicto FC, et al. Aneurysmal bone cyst of the ischium. Int Orthop 1985; 9:49-54

47. Boraini S, De Lure F, Campanacci L, et al. Aneurysmal bone cyst of the mobile spine. Report of 41 cases. Spine 2001; 26:27-35

48. Jerome C, Sophie B. Current treatment of Primer Anevrizmal bone Cysts. J Pediatr Orthop B 2006, 15:155-167 